\title{
An immunomodulating protein, Ling Zhi-8 (LZ-8) prevents insulitis in non-obese diabetic mice
}

\author{
K. Kino, K. Mizumoto, T. Sone, T. Yamaji, J. Watanabe, A. Yamashita, K. Yamaoka, K. Shimizu, K. Ko \\ and $\mathrm{H}$. Tsunoo \\ Biochemical Genetics Division, Meiji Institute of Health Science, Odawara, Japan
}

\begin{abstract}
Summary. Ling Zhi-8 (LZ-8), a novel and recently discovered immunomodulatory protein having in vivo immunosuppressive activity, was tested for in vivo effect against Type 1 (insulin-dependent) diabetes mellitus in the nonobese diabetic mouse, the disease having immunologically mediated aetiology in this animal. LZ-8 had mitogenic activity in vitro towards spleen cells of the non-obese diabetic mice as previously shown towards those of DBA/2 mice. Intraperitoneal administration of LZ-8 twice weekly into the mice $(10.3-12.6 \mathrm{mg} / \mathrm{kg}$ body weight) from 4 weeks of age prevented insulitis and an almost normal number of insulin producing cells were observed. Extreme insulitis and reduction of the number of insulin producing cells were observed in the pancreata of the untreated non-obese diabetic mouse.
\end{abstract}

No cumulative incidence of diabetes mellitus was observed in the LZ- 8 treated group, while cumulative incidences of $70 \%$ and $60 \%$ were observed in an untreated group followed up to 42 weeks of age when the incidence of diabetes was defined as a plasma glucose level of greater than $11 \mathrm{mmol} / \mathrm{l}$ and as a urine glucose level of greater than $2+$, respectively. $T$ cell subset population analysis was performed to further investigate the action of LZ-8 on the non-obese diabetic mouse which revealed that LZ-8 treatment increased in $\mathrm{L} 3 \mathrm{~T}_{4}^{+} / \mathrm{Lyt}^{-2^{+}}$ratio.

Key words: LZ-8, immunomodulator, NOD mouse, Type 1 (insulin-dependent) diabetes, insulitis, autoimmunity, T cell subset.
We have previously reported the isolation and characterization of a novel protein, named Ling Zhi-8 (LZ-8), which has an $\mathrm{M}_{\mathrm{r}}=13,100$ to 17,100 , a low carbohydrate content $(<1.3 \%)$, and an isoelectric point of 4.4 , from the mycelial extract of Ganoderma lucidum [1]. The complete amino acid sequence was determined and indicated that LZ-8 consists of a non-covalent homodimer of N-terminal blocked polypeptides bearing primary and predicted secondary structural similarities with immunoglobulin heavy chain [2]. In vitro, LZ-8 can haemagglutinate sheep, but not human, erythrocytes and has blastogenic activity towards mouse spleen cells; examination of its in vivo activity revealed an ability to inhibit systemic anaphylaxis and reduce the Arthus reaction [1]. Thus, LZ-8 seems to be a new mitogen and immunomodulator with therapeutic potential, whose mechanism of action needs clarification.

To further characterize LZ-8, we turned to the nonobese diabetic (NOD) mouse, an animal model of human Type 1 (insulin-dependent) diabetes of immunologically mediated aetiology. Aspects of disease in this model have been well studied, including a sex difference in incidence ( $80 \%$ cumulative incidence in females, $<20 \%$ in males, after 30 weeks of age) and various symptoms (i.e., hyperglycaemia, glucosuria) followed by deterioration (i.e., weight loss) before death [3]. Histologically, lymphocytic infiltration into the pancreatic islets (insulitis) begins in most animals after 5 weeks of age, leading to destruction of Beta cells and overt diabetes [4]. Various studies have implicated T cells [5-13], B cells [14], natural killer cells $[15]$ and macrophages $[16,17]$ as having roles in disease development. Immunological anomalies in NOD mice have also been described, including impaired cell-mediated immunity [18], interleukin-2 metabolism [15], and a unique class II MHC [19, 20].

The well defined immunological parameters of diabetes in the NOD mouse makes it a good choice for in vivo characterization of the immunomodulatory properties of LZ-8. The demonstrated suppressive activity of LZ-8 towards other immune reactions in vivo suggested that it might prevent insulitis in the NOD mouse.

\section{Materials and methods}

\section{Animals}

Four-week-old female NOD (unique I-A and no expression of I-E; total 43 mice), and DBA/2 mice (H-2 ; total three mice, specific pathogen-free grade) were purchased from Clea Japan, Inc. (Tokyo, Japan). All mice were housed under specific pathogen-free conditions before and during use in the experiments. 


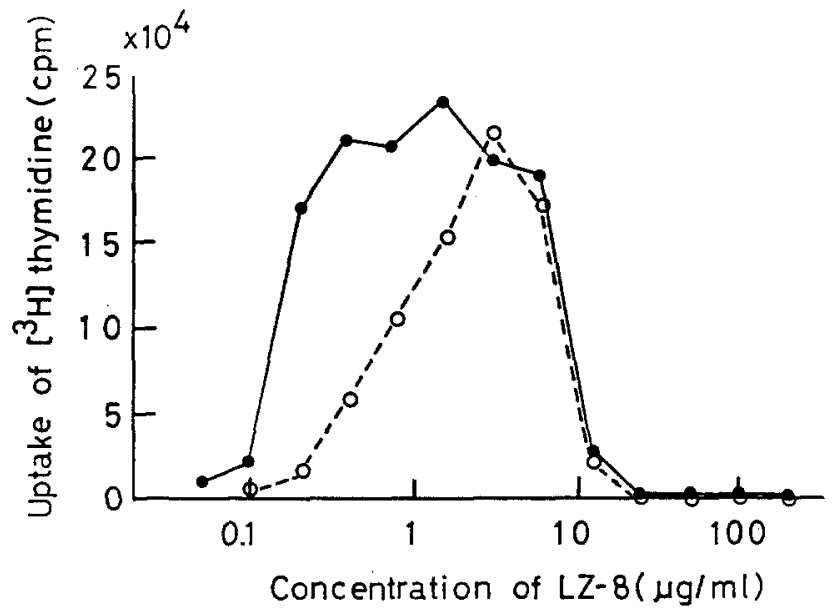

Fig.1. Effect of LZ-8 on proliferative response of NOD and DBA/2 mice spleen cells. Splenic lymphocyte fractions from non-diabetic NOD ( ) and DBA/2 (O) mice were cultured as described under "Materials and methods" at the indicated concentrations of LZ-8. Each point is the average of triplicate measurements

\section{Purification of $L Z-8$}

LZ-8 was purified from $G$. lucidum mycelia by gel filtration followed by ion-exchange chromatography as previously described and LZ-8 of greater than $97 \%$ purity, judged by Tricine-SDS polyacrylamide slab gel electrophoresis and Coomassie brilliant blue R staining [1], was used throughout this study.

\section{Proliferative response of spleen cells to $L Z-8$}

Three NOD (5-week-old, non-diabetic) or DBA/2 mice were killed by cervical dislocation and the spleens were removed using sterile technique. Pooled spleen cell preparations were obtained after passing the spleens through a wire screen ( 150 mesh), and erythrocytes in the suspensions were haemolysed with $0.16 \mathrm{~mol} / \mathrm{l} \mathrm{NH} \mathrm{NH}_{4} \mathrm{Cl}$, $0.17 \mathrm{~mol} / \mathrm{l}$ Tris-HCl, $\mathrm{pH}$ 7.7. After washing the cells with $10 \mathrm{ml}$ of RPMI 1640 and centrifugation at $150 \times \mathrm{g}$ for $10 \mathrm{~min}$, the cells were resuspended in $10 \mathrm{ml}$ of RPMI 1640 supplemented with $10 \%$ fetal calf serum 100 units $/ \mathrm{ml}$ penicillin, $100 \mu \mathrm{g} / \mathrm{ml}$ streptomycin, $200 \mathrm{mmol} / \mathrm{L}$-glutamate and $10 \mathrm{mmol} / \mathrm{LHEPES}, \mathrm{pH} 7.3$ as described by Strong et al. [21]. Cells $\left(0.1 \mathrm{ml}, 5 \times 10^{5} \mathrm{cells} / \mathrm{mI}\right)$ were seeded onto a 96-well microtitre plate (Falcon 3072) and various concentrations of LZ-8 in $0.1 \mathrm{ml}$ PBS were added. After incubation of the cells at $37^{\circ} \mathrm{C}$ under $5 \% \mathrm{CO}_{2}$ in air for $42 \mathrm{~h}, 10 \mu \mathrm{l}$ of $\left[{ }^{3} \mathrm{H}\right]$ thymidine $(0.25 \mu \mathrm{Ci}$, Amersham Japan, Tokyo, Japan) was added and the cells were incubated for a further $6 \mathrm{~h}$ under the same conditions. The cells were harvested onto a glass filter which was then dried and transferred to an Omnivial (Wheaton, New Jersey, USA). Toluene base scintillator $(2 \mathrm{ml})$ was added to the vials, which were then counted in a Betamatic II Liquid Scintillation Counter (Kontron, Zurich, Switzerland).

\section{Administration}

LZ-8 $(700 \mu \mathrm{g} / \mathrm{ml})$ in phosphate buffered saline was administered in $0.2 \mathrm{ml}$ doses throughout the experiments. Since a constant amount of LZ- 8 was given to the animals which grew during the course of the experiments, the amount given per body weight became decreased during the preventive experiments in Figure 3 and Table 1 from 12.6 and $10.3 \mathrm{mg} / \mathrm{kg}$, respectively, to $5.5 \mathrm{mg} / \mathrm{kg}$ at 42 weeks of age for the LZ-8 treated group in Figure 3 . In these experiments, treatment began from 4 weeks of age and was continued twice weekly by intraperitoneal injection. The mice in the control group were untreated. Urine-glucose was measured by Pretest kit (Wako Pure Chemical Industries, Ltd., Tokyo, Japan), and plasma-glucose in blood obtained from tail vein was measured with Glucose B-Test (Wako Pure Chemical Industries, Ltd.), twice monthly. Incidence of diabetes was defined twice monthly by both estimations of a plasma-glucose level of greater than $11 \mathrm{mmol} / \mathrm{l}$ and of an urine-glucose level of greater than $2+$.

\section{Histology and immunohistochemistry}

Paraffin sections (4-6 $\mu \mathrm{m})$ of NOD mouse pancreata were prepared from the 10 mice described in Table 1, and for histological analysis were stained with haematoxylin and eosin. Insulitis was estimated 10 islets in a mouse. For immunohistochemical analysis, the avidinbiotin-peroxidase complex (ABC) method of Hsu et al. [22] was used. The pancreas sections were pre-treated with $0.3 \% \mathrm{H}_{2} \mathrm{O}_{2}$ in methanol followed by normal swine serum. The sections were then incubated with guinea pig anti-porcine insulin antibody (IgG) for $1 \mathrm{~h}$ followed by biotinylated rabbit anti-guinea pig IgG antibody (IgG) (Lipshaw, Detroit, Mich., USA) for $30 \mathrm{~min}$ and then stained with an $\mathrm{ABC}$ kit (Vector Laboratories, Burlingame, Calif., USA) as described previously [23].

\section{Analysis of T cell subsets}

Mesenteric lymph node cells from 11-week-old untreated and LZ-8 treated (5 each) and 42-week-old untreated and LZ-8 treated NOD mice ( 3 each) were obtained after passing the nodes through a wire screen ( $150 \mathrm{mesh})$. Aliquots of cells $\left(1 \times 10^{6}\right.$ cells) were incubated with $1 \mu \mathrm{g}$ of FITC-conjugated anti-Thy 1.2 (30-H12), anti-Lyt-1 (537.3), anti-Lyt-2 (53-6.7), or $0.2 \mu \mathrm{g}$ of phycoerythrin-conjugated antiL3T4 (GK 1.5) (all from Becton-Dickinson, Mountain View, Calif., USA) at $4^{\circ} \mathrm{C}$ for $30 \mathrm{~min}$. Then, after fixation with $6 \%$ formalin, the cells $\left(1 \times 10^{4}\right.$ cells for each monoclonal antibody) were analysed by flow cytometry on a FACStar (Becton-Dickinson). In the case of the 11-week-old animals, five individual cell preparations were made and analysed, whereas for the 42-week-old animals, the lymph nodes were pooled into one cell preparation. Five individual spleen preparations were also made and analysed as described above for the 11-week-old animals.

Table 1. The effects of LZ-8 administration on NOD mice up to 19 weeks of age

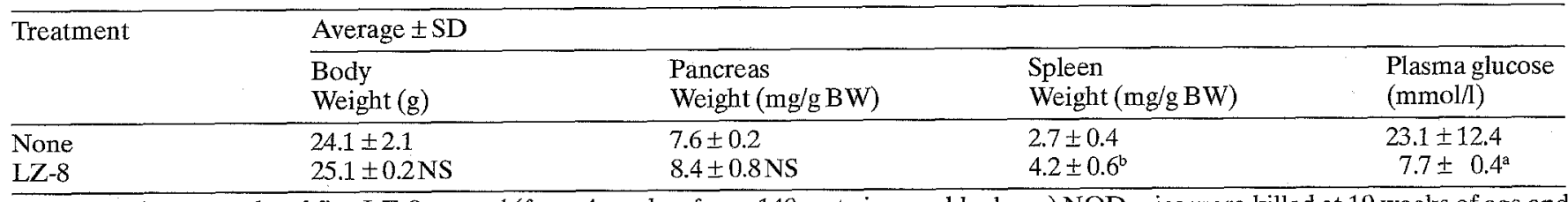

Five control untreated and five LZ-8 treated (from 4 weeks of age, $140 \mu \mathrm{g}$ twice weekly doses) NOD mice were killed at 19 weeks of age and the above measurements were taken. Statistical comparison of average values with those of untreated group, (NS); non-significant, ${ }^{a} p<0.05$, ${ }^{\mathrm{b}} p<0.01$ by Student's $t$-test. BW = body weight 


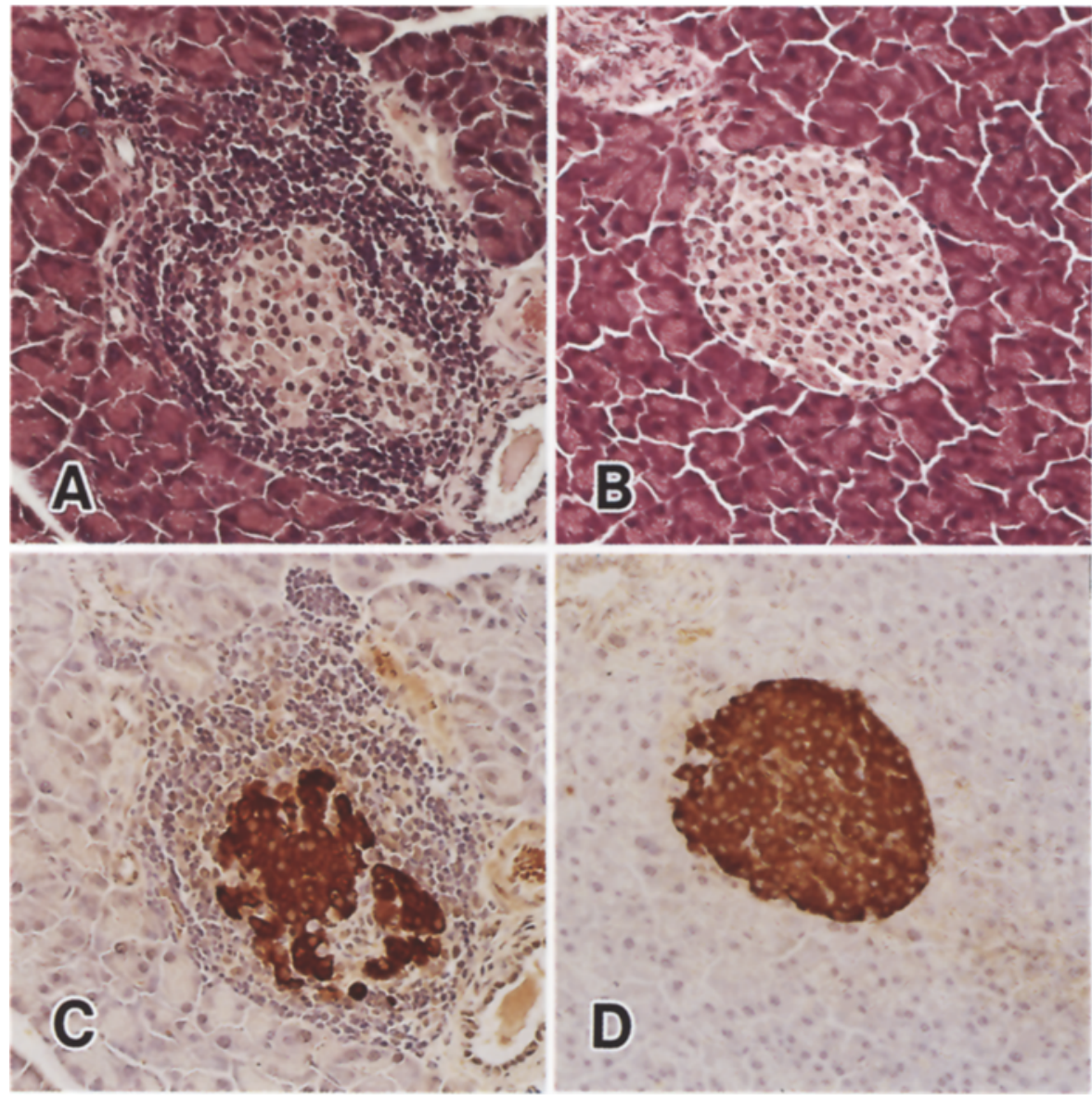

Fig. 2A-D. Histological and immunohistochemical examination of pancreatic islets of NOD mice with or without LZ-8 treatment. Pancreata of an untreated NOD mouse and that of an LZ-8 treated 19 weeks of age NOD mouse were stained with haematoxylin and $\operatorname{eosin}(\mathbf{A}, \mathbf{B})$ or by avidin-biotin peroxidase complex method after treatment with anti-insulin antibody $(\mathbf{C}, \mathbf{D})$

\section{Statistical analysis}

Statistical analysis was performed by Student's $t$-test.

\section{Results}

During LZ-8 purification, one-way biological specific activity was monitored was by proliferative response assay using DBA/2 mouse spleen cells [1]. This study describes the in vivo effects of LZ- 8 on diabetes in the NOD mouse but first, the biological effect of LZ-8 on NOD mouse spleen cells in vitro was examined by the same assay; using cells from 5-week old animals, maximum $\left[{ }^{3} \mathrm{H}\right]$ thymidine uptake occurred at $1.56 \mu / \mathrm{ml}$ and uptake decreased sharply at or above concentrations of $12.5 \mu \mathrm{g} / \mathrm{ml}$ (Fig.1). The response of NOD mouse spleen cells to LZ8 concentrations of less than $1.0 \mu \mathrm{g} / \mathrm{ml}$ was greater than the response of $\mathrm{DBA} / 2$ mouse spleen cells to similar concentrations of LZ-8 (Fig.1). Intraperitoneal administration of LZ-8 twice weekly into female NOD mice from 4 to 19 weeks of age prevented insulitis and typical pancreatic histological and immunohistochemical preparations are shown in Figure 2. The untreated mouse which had near-diabetic plasma glucose, showed massive lymphocytic infiltration (Fig.2A), whereas the LZ-8 treated mouse which was non-diabetic, appeared almost normal, with only slight infiltration (Fig.2B). Using anti-insulin antibody to detect pancreatic Beta cells, the entire islet was stained in the LZ-8 treated mouse (Fig. 2D), but only limited areas stained in the untreated mouse (Fig. 2C).

LZ-8 is a novel protein and side effects of its administration in vivo have not yet been described. Some effects of LZ-8 treatment in NOD mice are shown in Table 1; pancreatic histology, plasma and urine glucose levels, as well as whole body, pancreatic, and spleen weights were compared between five untreated and five LZ-8 treated mice at 19 weeks of age. LZ-8 treated mice had nondiabetic plasma glucose levels while the average was tripled in untreated mice, with three out of five mice having both extremely elevated plasma $(21.5-38.0 \mathrm{mmol} / 1)$ and urine $(3+)$ glucose levels $(p<0.05)$. Histological examination revealed only slight insulitis in $80 \%$ of LZ-8 treated mice whereas in most cases, untreated mice had severe insulitis with or without decrease in islet number. Body and pancreatic weights were not significantly changed by LZ- 8 treatment, although the averages were higher for LZ-8 treated animals. Thus, the major side effect of LZ-8 treatment was an increase in spleen weight. This was not accompanied by lymphadenopathy and microscopic structure of spleens from both the untreated and LZ-8 treated mice were basically similar, except for higher numbers of lymphatic nodules and a larger germinal centre in spleens of LZ-8 trested mice (data not shown). There were no other noticeable side effects judging from the behaviour of the mice during the experiments or visual examination of spleen, liver, pancreas, kidney, lung, or intestine. Acute toxicity of LZ-8 at $10 \mathrm{mg} / \mathrm{kg}$ ad- 
Table 2. T cell subset analysis of NOD mice after LZ-8 treatment up to 11 and 42 weeks of age

\begin{tabular}{|c|c|c|c|c|c|c|}
\hline \multirow{2}{*}{$\begin{array}{l}\text { Age in week } \\
\text { (Organ) }\end{array}$} & \multirow{2}{*}{ Treatment } & \multicolumn{5}{|c|}{ Cells stained (\%) } \\
\hline & & Thy 1.2 & Lyt-1 & Lyt-2 & L3T4 & L3T4/Lyt-2 \\
\hline 11 & None & $75.5 \pm 3.0$ & $84.1 \pm 1.8$ & $22.7 \pm 1.1$ & $59.9 \pm 1.0$ & $2.64 \pm 0.14$ \\
\hline$(\mathrm{LN})$ & LZ-8 & $68.1 \pm 4.1^{\mathrm{a}}$ & $77.0 \pm 4.3^{a}$ & $18.0 \pm 2.3^{\mathrm{b}}$ & $53.6 \pm 2.8^{\mathrm{b}}$ & $3.01 \pm 0.30$ \\
\hline (Spleen) & LZ-8 & $39.1 \pm 7.4$ & $54.9 \pm 7.1$ & $12.2 \pm 2.2^{\mathrm{a}}$ & $33.5 \pm 2.6$ & $2.81 \pm 0.35^{\mathrm{a}}$ \\
\hline 42 & None & 73.9 & 73.5 & 28.8 & 47.9 & 1.66 \\
\hline$(\mathrm{LN})$ & $\mathrm{LZ}-8$ & 72.8 & 76.1 & 23.3 & 50.0 & 2.15 \\
\hline
\end{tabular}

Cell preparation was made and analysed as described in "Materials and methods". ${ }^{a} p<0.05,{ }^{b} p<0.01$ by Student's $t$-test. LN $=$ lymph node

ministered i.v. into Institute of Cancer Research USA (ICR) mice was low as body weight dropped slightly one day later but was normal thereafter (data not shown).

The ability of LZ-8 to prevent diabetes incidence was examined and intraperitoneal administration of LZ-8 twice weekly into female NOD mice from 4 weeks of age completely prevented incidence until 42 weeks of age (Fig. 3). At the same time, in the control untreated mice, $50 \%$ cumulative incidence was observed at 26 and 32 weeks of age, $70 \%$ and $60 \%$ at 40 weeks when incidence was defined as a plasma glucose level of greater than $11 \mathrm{mmol} / 1$ and as a urine glucose level greater than $2+$, respectively. We could detect anti-LZ-8 IgG in the sera of LZ- 8 treated mice after 28 and 38 weeks of age in the experiment of Figure 3 (data not shown). However, there was no anaphylactic reaction or other noticeable side effects judging from the behaviour of the mice during experiments.

To examine the in vivo action of LZ-8 in more detail, $T$ cell subset population analysis was performed (Table 2). LZ-8 treatment leads to significant $(p<0.05$ and $p<0.01$ ) decreases after 11 weeks in all subpopulations measured from lymph nodes. Analysis of another secondary lymphoid organ, the spleen, provided similar findings in that LZ-8 treatment lead to decreases in all subpopulations and an increase in $\mathrm{L} 3 \mathrm{~T}^{+} / \mathrm{Lyt}-2^{+}$ratio after 11 weeks (Table 2). By 42 weeks, differences in

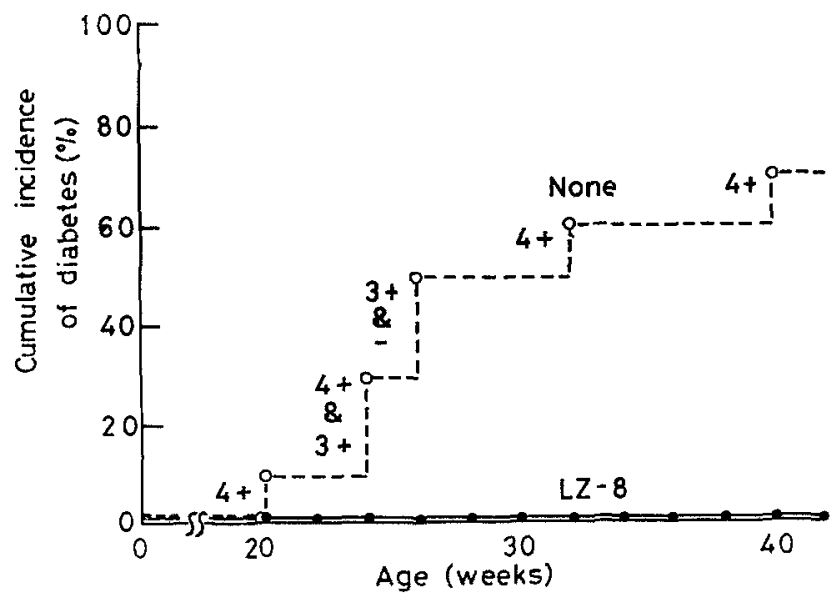

Fig.3. Effect of $\mathrm{LZ}-8$ administration on incidence of diabetes mellitus in NOD mice. Ten control untreated and ten LZ-8 treated NOD mice were observed for onset of diabetes as described in "Materials and methods". Symbols $(-, 3+, 4+)$ are urine glucose levels of mice diagnosed as diabetic with plasma glucose level greater than $11 \mathrm{mmol} / \mathrm{l}$
Thy $1.2^{+}$, Lyt $-1^{+}$, and $\mathrm{L}_{3} \mathrm{~T}^{+}$subpopulations became diminished, mostly due to decreases in untreated subpopulations. We also analysed $\mathrm{T}$ cell subsets of lymph node cells obtained from a diabetic NOD mouse (42weeks-old) and the results were; $86.7 \%$, Thy $1.2^{+} ; 80.6 \%$, Lyt- $1^{+} ; 31.6 \%$, Lyt- $2^{+} ; 48.7 \%, \mathrm{~L} 3 \mathrm{~T}^{+}$; and the ratio of $\mathrm{L} 34^{+} / \mathrm{Lyt}^{+}{ }^{+}$was 1.54 . Although these values were obtained from only one mouse, the subpopulations of Lyt $-2^{+}, \mathrm{L} 3 T 4^{+}$, and the ratio of $\mathrm{L} 3 \mathrm{~T} 4{ }^{+} / \mathrm{Lyt}_{-} 2^{+}$were close to 42-week-old non-diabetic untreated NOD mice (Table 2). The overall effect of LZ-8 treatment seemed to be an increase in L3T4 $4^{+} / \mathrm{Lyt}-2^{+}$ratio which was evident after both 11 and 42 weeks. Coincidentally, LZ-8 treatment had no effect on the $T$ cell subset population in ICR mouse lymph nodes or spleen at the same times (data not shown).

\section{Discussion}

This study describes the effect of LZ-8 on insulitis in NOD mice, based on its previously shown in vivo immunomodulatory activities. Under the described treatment conditions (twice weekly, intraperitoneal injections, $140 \mu \mathrm{g}$ per dose), mice received approximately $10 \mathrm{mg} / \mathrm{kg}$ body weight of LZ-8 at the beginning of treatment, although this became reduced to $5.5 \mathrm{mg} / \mathrm{kg}$ due to weight increase during the experiment. This treatment plan was clearly preventive for insulitis in the NOD mice and seemed to be effective immunogenically and mitogenically in other studies. For instance, LZ-8 prevented anaphylaxis in CFW mice at dosages of between 6.9 and $7.4 \mathrm{mg} / \mathrm{kg}$ body weight [1]. Also, LZ-8 administered to DBA/ 2 mice at $10 \mathrm{mg} / \mathrm{kg}$ body weight resulted in stimulated $\left[{ }^{3} \mathrm{H}\right]$ thymidine uptake by spleen cells from these mice (unpublished data). The in vitro activity of LZ-8 is clearly dose dependent (Fig. 1, [1]), therefore in vivo dose dependency studies need to be done. Nevertheless, the present treatment plan was effective for prevention of insulitis although it may not have been optimal for administration effect. The only side effect of treatment seemed to be increased spleen weight. LZ-8 also seemed to have low toxicity.

The underlying mechanism of the in vivo effects of LZ-8 on insulitis in the NOD mouse is unknown but it may be interesting to compare it with two other immunomodulatory drugs, cyclosporine and OK 432. All are able to prevent diabetes and decrease severity of insulitis if treatment is started before insulitis occurs (i.e., at about 4 weeks of age) $[15,24]$. However, the charac- 
teristics of cyclosporine and OK 432 are very different. Cyclosporine, a fungal cyclic polypeptide, is a potent inhibitor of $I L-2$ production and T cell activation in vitro and suppressor of organ allograft in vivo [25], while OK 432, a streptococcal preparation, increases IL-1 and IL-2 production and activates macrophages and killer $T$ cells in vitro [15] and is an in vivo immunopotentiator used for cancer chemotherapy [26,27]. On the other hand, LZ-8 is mitogenic towards mouse spleen cells as well as unfractionated human peripheral blood lymphocytes containing $10 \%$ macrophages and stimulates the production of IL-1 and IL-2 as well as other lymphokines in vitro (unpublished data), although it is preventive in vivo against immune responses such as systemic anaphylaxis and the Arthus reaction [1]. Our recent experiments revealed that LZ-8 could significantly suppress pokeweed mitogen-induced or antigen-specific IgG production by human peripheral blood lymphocytes in vitro (unpublished data). These results point out that suppressor T cells are generated by the LZ-8 stimulation and the mechanism of suppression resembles the generation of suppressor effector $\mathrm{T}$ cells by Con $\mathrm{A}$ stimulation $[28,29]$. It appears that in the NOD mouse, the occurrence of diabetes seems to be mainly determined by a balance between autoimmunity and suppression and that immunotherapies such as those described above and others [30] can be effective in altering the course of disease and may be useful in the treatment of human disease. While the precise mechanism of LZ-8 action in vivo was not determined, it did alter subset distribution of $T$ cells, which are known to play a role in disease. Our unpublished results also suggest an activity towards macrophages. Changes in T lymphocyte subsets have also been noted in human diabetes mellitus [31]. Being mitogenic and stimulatory towards lymphokine production in vitro, LZ-8 may also have some further, yet unknown action to explain its immunomodulatory activity in vivo. LZ-8 resembles lectins in biological activity of lymphocyte activation in vitro, although it is not a lectin per se [1], and it bears structural similarity to immunoglobulin domains [2]. These points, along with the existence of suppressive [32] or suppressor cell-inducing lymphokines [33] and the yet unchecked possibility that LZ-8 affects their production, may provide keys to understanding its mechanism of action. It is hoped that in the future, LZ-8 will also be clinically useful as well as providing insight into the diabetic disease process, but further investigation is necessary.

\section{References}

1. Kino K, Yamashita A, Yamaoka K, Watanabe J, Tanaka S, Ko K, Shimizu K, Tsunoo H (1989) Isolation and characterization of a new immunomodulatory protein, Ling Zhi-8 (LZ-8), from Ganoderma lucidum. J Biol Chem 264: 472-478

2. Tanaka S, Ko K, Kino K, Tsuchiya K, Yamashita A, Murasugi A, Sakuma S, Tsunoo H (1989) Complete amino acid sequence of an immunomodulatory protein, Ling Zhi-8 (LZ-8): an immunomodulator from a fungus, Ganoderma lucidum having similarity to immunoglobulin variable regions. J Biol Chem 264: 16372 16377

3. Makino S, Kunimoto K, Muraoka Y, Mizushima Y, Katagiri K, Tochino Y (1980) Breeding of a non-obese, diabetic strain of mice. Exp Anim 29:1-13

4. Fujita T, Yui R, Kusumoto Y, Serizawa Y, Makino S, Tochino Y (1982) Lymphocyte insulitis in a 'non-obese diabetic (NOD)' strain of mice: an immunohistochemical and electron microscope investigation. Biomed Res 3: 429-443

5. Miyazaki A, Hanafusa T, Yamada K, Miyagawa J, Fujino-Kurihara $H$, Nakajima H, Nonaka K, Tarui S (1985) Predominance of $T$ lymphocytes in pancreatic islets and spleen of pre-diabetic non-obese diabetic (NOD) mice: a longitudinal study. Clin Exp Immunol 60: 622-630

6. Koike T, Itoh Y, Ishii T, Ito I, Takabayashi K, Maruyama N, Tomioka H, Yoshida S (1987) Preventive effect of monoclonal anti-L3T4 antibody on development of diabetes in NOD mice. Diabetes 36: 539-541

7. Wang Y, Hao L, Gill RG, Lafferty KJ (1987) Autoimmune diabetes in NOD mouse is L3T4 T-lymphocyte dependent. Diabetes 36: $535-538$

8. Harada M, Makino S (1986) Suppression of overt diabetes in NOD mice by anti-thymocyte serum or anti-Thy 1.2 antibody. Exp Anim 35: 501-504

9. Harada M (1987) Immune disturbance and pathogenesis of nonobese diabetes-prone (NOD) mice. Exp Clin Endocrinol 89: 251-258

10. Makino S, Harada Y, Kishimoto Y, Hayashi Y (1986) Absence of insulitis and overt diabetes in athymic nude mice with NOD genetic background. Exp Anim 35: 495-498

11. Miller BJ, Appel MC, O'Neil JJ, Wicker LS (1988) Both the Lyt-2 ${ }^{+}$and $\mathrm{L} \mathrm{T} 4^{+} \mathrm{T}$ cell subsets are required for the transfer of diabetes in nonobese diabetic mice. $J$ Immunol 140: 52-58

12. Bendelac A, Carnaud C, Boitard C, Bach JF (1987) Syngeneic transfer of autoimmune diabetes from diabetic NOD mice to healthy neonates: Requirement for both $\mathrm{L}_{3 \mathrm{~T}} 4^{+}$and Lyt-2 ${ }^{+}$cells. J Exp Med 166: 823-832

13. Wicker LS, Miller BJ, Mullen Y (1986) Transfer of autoimmune diabetes mellitus with splenocytes from nonobese diabetic (NOD) mice. Diabetes 35:855-860

14. Kanazawa Y, Komeda K, Sato S, Mori S, Akanuma K, Takaku F (1984) Non-obese-diabetic mice: immune mechanisms of pancreatic B-cell destruction. Diabetologia 27:113-115

15. Toyota T, Satoh J, Oya K, Shintani S, Okano T (1986) Streptococcal preparation (OK-432) inhibits development of Type I diabetes in NOD mice. Diabetes 35: 496-499

16. Lee KU, Amano K, Yoon JW (1988) Evidence for inital involvement of macrophage in development of insulitis in NOD mice. Diabetes 37: 989-991

17. Charlton B, Bacelj A, Mandel TE (1988) Administration of silica particles or anti-Lyt2 antibody prevents B-cell destruction in NOD mice given cyclophosphamide. Diabetes 37: 930-935

18. Kataoka S, Satoh J, Fujiya H, Toyota T, Suzuki R, Itoh K, Kumagai K (1983) Immunological aspects of the nonobese diabetic (NOD) mouse: abnormalities of cellular immunity. Diabetes 32 : $247-253$

19. Achea-Orbea H, McDevitt $\mathrm{HO}$ (1987) The first external domain of the nonobese diabetic mouse class II I-A B chain is unique. Proc Natl Acad Sci USA 84: 2435-2439

20. Hattori M, Buse JB, Jackson RA, Glimcher L, Dorf ME, Minami M, Makino S, Moriwaki K, Kazuya H, Strauss WM, Seidman JG, Eisenbarth GS (1986) The NOD mouse: recessive diabetogenic gene in the major histocompatibility complex. Science 231: 733735

21. Strong DM, Ahmed AA, Thurman GB, Sell KW (1973) In vitro stimulation of murine spleen cells using a microculture system and a multiple automated sample harvester. J Immunol Methods 2:279-291

22. Hsu SM, Raine L, Fanger H (1981) Use of avidin-biotin-peroxidase complex $(\mathrm{ABC})$ in immunoperoxidase techniques: a com- 
parison between $\mathrm{ABC}$ and unlabeled antibody ( $\mathrm{PAP}$ ) procedures. J Histochem Cytochem 29:577-580

23. Kino K, Mizumoto K, Watanabe J, Tsunoo H (1987) Immunohistochemical studies on hemoglobin-haptoglobin and hemoglobin catabolism sites. J Histochem Cytochem 35: 381-386

24. Mori Y, Suko M, Okudaira H, Matsuba I, Tsuruoka A, Sasaki A, Yokoyama H, Tanase T, Shida T, Nishimura M, Terada E, Ikeda $Y$ (1986) Preventive effects of cyclosporin on diabetes in NOD mice. Diabetologia 29:244-247

25. Shevach EM (1985) The effects of cyclosporin A on the immune system. Ann Rev Immunol 3: 397-423

26. Torisu M, Katano M, Kimura Y, Itoh H, Takasue M (1983) New approach to management of malignant ascites with a streptococcal preparation, OK-432. I. Improvement of host immunity and prolongation of survival. Surgery 93: 357-364

27. Watanabe Y, Iwa T (1984) Clinical value of immunotherapy for lung cancer by the streptococcal preparation OK-432. Cancer 53: 248-253

28. Tadakuma T, Pierce CW (1976) Site of action of a soluble immune response suppressor (SIRS) produced by concanavalin A-activated spleen cells. J Immunol 117: 967-972

29. Kaufman DB, Carnard C, Stach JL, Bach JF (1976) The suppressive effect of a supernate from concanavalin A-activated lymphocytes. Cell Immunol 47: 153-162

30. Formby B, Miller N, Peterson CM (1988) Adoptive immunotherapy of diabetes in autologous nonobese diabetic mice with lymphoid cells ex vivo exposed to cyclosporin plus interleukin 2. Diabetes 37: 1305-1309

31. Rossini AA, Mordes JP, Like A (1985) Immunology of insulindependent diabetes mellitus. Ann Rev Immunol 3: 289-320

32. Krakauer RS, Waldmann TA, Strober W (1976) Loss of suppressor T cells in adult NZB/NZW mice. J Exp Med 144: 662673

33. Almawi WA, Dolphin PJ, Thies RL, McMaster WR, Levy JG, Pope BL (1988) Suppressor cell-inducing factor: A new lymphokine secreted by a natural suppressor cell line with natural cytotoxic activity I: purification to apparent homogeneity and initial characterization of suppressor cell-inducing factor. J Immunol 141:2529-2535

Received: 23 March 1990

and in final revised form: 3 September 1990.

Dr. K. Kino

Biochemical Genetics Division

Meiji Institute of Health Science

Naruda, Odawara 250

Japan 